\title{
ATEBE
}

Dinî Araștırmalar Dergisi Journal for Religious Studies e-ISSN: 2757-5616

ATEBE Dergisi / Journal of ATEBE

Sayı: 6 (Aralık / December 2021), 199-203.

\section{İdeolojik Hadisçiliğin Tarihî Arka Planı. Mehmet Emin Özafşar. Ankara: Otto Yayınları, 2017.}

\section{Değerlendiren/Reviwed by \\ Ömer Ali Özdemir}

Yüksek Lisans Öğrencisi, Selçuk Üniversitesi, Sosyal Bilimler Enstitüsü, Hadis Anabilim Dalı

M.A. Student, Selçuk University, Institute of Social Sciences, Department of Hadith

$$
\text { Konya, Turkey }
$$

mrlzdmr.9650@gmail.com

orcid.org/ 0000-0002-9524-2680

https://ror.org/045hgzm75

\section{Makale Bilgisi / Article Information}

Makale Türü / Article Types: Kitap Değerlendirmesi / Book Review

Geliş Tarihi / Date Received: 5 Kasım/November 2021

Kabul Tarihi / Date Accepted: 14 Aralık/December 2021

Yayın Tarihi / Date Published: 31 Aralı/December 2021

Yayın Sezonu / Pub Date Season: Aralık/December

Atıf / Cite as: Özdemir, Ömer Ali. “İdeolojik Hadisçiliğin Tarihî Arka Planı. Mehmet Emin Özafşar. Ankara: Otto Yayınları, 2017”. ATEBE 6 (Aralık 2021), 199-203. https://doi.org/10.51575/atebe.1019819

İntihal / Plagiarism: Bu makale, iTenticate yazılımınca taranmıştır. İntihal tespit edilmemiştir/This article hasbeen scanned by iTenticate. No plagiarism detected.

Etik Beyan/Ethical Statement: Bu çalışmanın hazırlanma sürecinde bilimsel ve etik ilkelere uyulduğu ve yararlanılan tüm çalışmaların kaynakçada belirtildiği beyan olunur/It is declared that scientific and ethical principles have been followed while carrying out and writing this study and that all the sources used have been properly cited (Ömer Ali Özdemir).

Yayıncı / Published by: Ankara Sosyal Bilimler Üniversitesi / Social Sciences University of Ankara. Bu makale Creative Commons Alıntı-GayriTicariTüretilemez 4.0 (CC BY-NC 4.0) Uluslararası Lisansı altında lisanslanmıştır. This article is an open access article distributed under the terms and conditions of the Creative Commons Attribution-NonCommercial-NoDerivatives 4.0 (CC BY-NC 4.0) International License. 
Ömer Ali Özdemir

İdeolojik Hadisçiliğin Tarihî Arka Planı. Mehmet Emin Özafşar. Ankara: Otto

Yayınları, 2017.

Öz

Peygamber'in vefatından sonraki ilk üç asırda meydana gelen olaylar silsilesi bütün ilim alanlarını etkilediği gibi hadis ilmini ve hadis tarihini de derinden etkilemiștir. Özellikle Abbasiler döneminde hayat bulan Mihne olayı ve "Halku'l Kuran"ın dayatılması ve ortaya çıkan "haşevilik" olgusu hadis tarihinin arka planını bilmenin önemini hissettirmiştir. Mihne olayının ve haşevîlik olgusunun yaşandığı dönemde hadis literatürüne pek çok katkı sağlanmıștır. Ancak dönemin zengin kaynaklarını ve hadis tarihini bilmeden okuma ve çalışma yapmanın yanlış değerlendirmelere yol açacağı açıktır. Mehmet Emin Özafşar'ın İdeolojik Hadisçiliğin Tarihsel Arka Planı adlı kitabı, bu yanlış anlamaların önüne geçilmesi adına ilahiyat öğrencileri ve hadis meraklıları için önemli bilgiler içermektedir.

Anahtar Kelimeler: Hadis, Mihne, Halku'l-Kur'ân, Mutezile, Haşviyye.

\title{
The Historical Background of Ideological Hadithism. Mehmet Emin Özafșar. Ankara: Otto Publications, 2017.
}

\begin{abstract}
The sequence of events that took place in the first three centuries after the Prophet died deeply affected the science and history of hadith, as well as all fields of science. Particulary, the event of al-Mihnah that came to life during the Abbasid period and the imposition of "Khalq al-Qur'an" and the emerging "hashawiyyah" phenomenon indicated the importance of knowing the background of the history of hadith. Many contributions were made to the hadith literature in the period when the event of al-Mihna and the phenomenon of hashawiyyah were experienced. However, it is obvious that reading and doing research without knowing the rich sources of the period and the history of hadith will lead to wrong evaluations. Mehmet Emin Özafşar's book, The Historical Background of Ideological Hadithism, contains important information for theology students and hadith enthusiasts that would help them avoid these misunderstandings.
\end{abstract}

Keywords: Hadith, al-Mihna, Khalq al-Qur'an, Mutazilah, Hashawiyyah.

Tarih, meydana gelen olayların yaşandığı zamanı, silsileli şekilde tespit eden ilim dalıdır. ${ }^{1}$ Tarih tanımından yola çlkarak Hadis tarihini, Peygamberimiz'den (s.a.s) günümüze kadar hadis sahasında yaşanan bilgi birikimine ve buna dair tarihi arka planına ayna tutup zihinleri berraklaştıran alt ilim dalı olarak tarif edebiliriz. Hadis ilmi, rivayet olunan hadislerin söylendiği ortamdan tutup dört halife zamanında yaşananlar, Emevî ve Abbâsî devirlerindeki baskılar ve diğer dönemlerdeki birikimler gibi faktörlerden etkilenmiştir. Bu kitap sadece Mihne olayını ayrıntılı olarak ele almış olsa da, yine de hadis tarihi alanına önemli bir katkı sağlamıştır.

Hadis ilminin ve birikiminin toplumsal ve entelektüel dönüşümden geçtiği en önemli dönemlerden birisi, Mihne ve Halku'l-Kur'ân dayatmasının yaşandığı zaman aralığıdır. Elimizde bulunan ve tanıtımını yapmaya çalıştığımız kitap, Prof. Dr. Mehmet Emin Özafşar tarafından kaleme alınmış ve ilk baskısı 1999 yllında raflarda yerini almıștır. İkinci baskısı Ocak 2015'te, üçüncü baskısı ise Mart 2017'de gerçekleştirilmiştir. Elimizdeki nüsha kitabın son baskısına aittir. Giriș ve sonuç bölümü haricinde, iki bölümden oluşmaktadır. Birinci bölüm; Hicri İlk Üç Asrın Panoramasl, Halku'l-Kur'ân Olayl, Mihnenin Arka Planı, Neden "Kur'ân Mahluktur" Sloganı?, Mihne Süreci, Direncin Haklı Zaferi, Yolların Ayrılış Noktası, Haşevilik Boy Salıyor, Mihne Olayının Perçinlediği Nefretin Rivayetlerin Dilindeki İfadesi ve Biyografi Literatürüne Katkısı alt başlıklarından

Mustafa Fayda, “Tarih”, Türkiye Diyanet Vakfi İslam Ansiklopedisi (Erişim 5 Kasım 2021). 
İdeolojik Hadisçiliğin Tarihî Arka Planı. Mehmet Emin Özafșar. Ankara: Otto Yayınları, 2017

oluşmaktadır. İkinci bölüm ise; Fırkaların Tarihine Bakış, Hz Peygamber ve Mesajı, Mihne veya Halku'l-Kur'ân Fitnesi ve Haşeviler, Haşeviler ve Hasan b. Ziyâd, Hașeviler ve Muhammed $b$. Şuca' es-Selcî konulu alt başliklardan oluşturulmuştur.

Giriş bölümünde, hadis tarihi ile ilgili sistematik eserlerin günümüze yakın yazıldığından ve tabakât kitaplarındaki bilgilerin ise hadis tarihini yansıtacak nitelikte olmadığından bahsedilmiştir. Yazar, 20. yüzyılda İzmirli İsmail Hakkı, Babanzâde Ahmed Naim, Tayyib Okiç ve Fuat Sezgin tarafından hadis tarihine dair kitapların telif edildiğini ifade ettikten sonra Talat Koçyiğit'in kitabında yer alan bazı eksik yönlere dikkat çekmiştir. Hadis tarihini dönemlere ayırmak suretiyle; bu dönemlerin hadis tarihiyle okunmasının zorunluluğuna dikkat çekmiştir. Tasnif dönemlerinde gelișen konjektürel durumların görüşülmesi ve dönemin etkilerinin sorgulanarak, hadis râvilerinin bu olaylardan etkilenmeleri de tespit edilmiştir. Çünkü başlangıçta yaşanan Berbehârî kalkışmasının, İbn-i Teymiye'nin etkisinin, Vehhabîlik isyanının ve Selefî-Haşevî görüşlerin, ravileri etkilediği düşünülmüştür (13-31). Bu bölümde yazar, hadis tarihinin dönemlere ayrılmasının gerekliliğini vurgulasa da bu bizce zor olacaktır. Çünkü geçmişten günümüze gelen verilerle hareket edebiliyoruz. Hadis tarihini ele alabilmek için o dönemlerde kaybolan kitapların elimizde mevcut olması gereklidir.

Birinci Bölümde; ilk üç asırda yaşanan kültürel, sosyal ve siyasal olaylar; peş peșe ele alındıktan sonra önce Emevî mihnesi daha sonra Abbâsi devirlerinde geçen mihne sürecinin kalıcı olmasına kapı araladığı belirtilmiştir. Emîn ve Me'mûn arasında yaşanan çekişmelerden Me'mûn'un galip gelip hilafeti ele alması ve iç tehditleri bastırıp diş tehditler için sefere çıktığında bir mektupla mihne sürecini başlattığı kaydedilmiştir. Yazar; baskı sürecinin kişilere dayattırmaya çalıștığı şeyin Kur'an'ın mahlukluğunu kabul ettirmek olduğunu belirterek, bunun nedenini muhalefeti saf dışı bırakmak şeklinde yorumlamıştır. İlk mektuptan sonra ikinci ve üçüncü mektupların varlığından bahsedildiği bu bölümde; mektupların içeriğinin Ahmed $\mathrm{b}$. Hanbel ve diğer muhaddislere baskı unsuru içerdiği açılanmıştır. Me'mûn'dan sonra Mu'tasım ve Vâsiķ devirlerinde Mihne devam etmiş, ancak bunun psikolojik baskı şeklinde sürdüğü beyan edilmiştir. Mütevekkil ile sona eren Mihne sürecinin, muhaddislerin devletle uzlaşmaya gitmesiyle sona erdiği belirtilmiştir. Bu duruma müteakip, karşı itibarsızlaştırma harekâtına başlanarak Mihne'de olumlu cevap veren Yahyâ b. Maîn ve Ali b. el-Medînî gibi muhaddislerle yolların ayrıldığı kaleme alınmıştır. Hatta Haşeviler, kendileri gibi düşünmeyen râvilerin iman dışı olduğunu söyleyecek kadar ağır ithamlara yer vermişlerdir. Yazar; itibarsızlaştırma sürecinden sonra Ehl-i Sünnet-Ehl-i Hadîs diye anılan Ahmed b. Hanbel ve taraftarlarının muhalifler tarafından "Haşeviyye" diye anıldığını belirtmiştir. Bu lakapla anılmalarını kendisinin ortaya koyduğu "Vulgarize İslam" kavramıyla açıklamıştır (s. 31-83). Kitabın başlığı "İdeolojik Hadisçiliğin Tarihi Arka Planı" iken sadece Mihne sürecine rastlamak hayal kırıklığına neden olmuştur. Çok genel ve iddialı bir başlıkta, en azından hadis tarihine etki etmiş iki veya üç farklı olayı görmek isterdik. Bir diğer noktaysa, birinci bölümdeki başlıklarda verilen mihne ile ilgili bilgilerde okuyucu tekrar ettiği hissini yaşıyor.

İkinci bölümde; Cahiliye dönemindeki bataklık ortamından; Teslîs ve Hulûl'a inanan, gök cisimlerine tapan ve Allah'ı reddeden inanışların doğduğu kaydedilmiştir. Yazar; Hz. Muhammed'in (s.a.s) bu debdebeli çukurda yaşayanların ilgisini nasıl çektiği noktasında şaşkınlığın olduğunu ifade etmiştir. Sonra onlara rableri hakkında nelerin mümkün olduğunu öğreterek, davranışlarının nasıl olması noktasında eğitim vererek aralarında ilim-amel bütünlüğünün oluşmasını sağlamıştır. Bu bütünlüğe ulaşmada sahabenin önünde rehberinin olması, ilim-amel bütünlüğüne götürecek formüle kafa 
yormamalarına neden olduğu şeklinde çlkarıma yer verilmiştir. Efendimizin vefatından sonra sırayla Hz. Ebû Bekir, Hz. Ömer, Hz. Osman, Hz. Ali, Hz. Hasan ve Emevîler döneminin yaşandığı ve bu dönemlerde gerçekleșen olayların ne gibi gruplar ortaya çıkardığı söz konusu edilmiştir.

Eserde; Râşid halifeler zamanında farklı grupların Müslüman olması ve eski dinlerindeki mitolojileri rivayet alanına taşımaları, Mu'tezile ve Şîa gibi grupların mitolojileri benimsemelerine sebep olmuştur. Abbâsîler devrinde de İbnü'l-Mukaffa' gibi şahısların başka medeniyetlerden tercüme faaliyetleriyle oluşturdukları görüşlerini Haşeviyye üzerinde baskı unsuru (mülhidlere cevaben denerek) olarak kullandıkları aktarılmıştır. Mihne ve Kur'an'ın mahlukluğunu dayattırmasını da bu sürecin doğurduğu ifade edilmiștir. Hem Mihne'de hem de Haşeviyye'nin devletle uzlaştığı dönemde ki baskıları durduran, sis bulutlarını dağıtanın ise Ebü'l-Hasan el-Eş'arî olduğu kaydedilmiştir.

Mihne olayının șiddetlendiği dönemde, cerh alanındaki kitapların cerh edilen kişilerle dolup taştığından bahsedilmiştir. Yazar; bu bölümde cerh edilenler hakkında ki rivayetlere de yer vermiștir. Bu rivayetlerde; şiddetli ihtilafın yaşandığı Mihne döneminde atanılan kadıların, Ebû Hanîfe'ye ve diğer fakihlere yakınlığı bulunmasının, kadılara gelecek eleștirin onların yerine fakihlere yönelmesine sebebiyet vererek itibarlarının sarsılmak istendiği vurgulanmıştır. Hatta alenen haklarında kitaplar yazıldığı da bizlere sunulmuştur.

İkinci bölümün son iki konusunu, dönemin itibarsızlaştırılan iki âlimi oluşturmuştur. Bunlardan ilki Hasan b. Ziyâd'tır. Fıkıhta büyük bir imam ve ilimde itibar edilen bir kişilik olduğundan bahsedilmiştir. Yazar; Hasan b. Ziyâd'ın uzun yaşayanlardan olduğunu, lakin doğum tarihinin tam olarak bilinememekle beraber bir rivayete göre doksan küsur sene yaşadığını ifade etmiștir. Sonra Hasan b. Ziyad'ın Halku'l-Kur'an fitnesine bulaşanlardan olduğu zikredilmiştir. Cerh kitaplarında ağır ş̧ekilde eleştirildiğinden bahsedilmiștir. Hasan b. Ziyâd'ı eleștiren kişilerden birincisinin Ebû Ca'fer el-Ukaylî, daha sonra Hatîb el-Bağdâdî, İbn-i Adî, Osmân b. Saîd ed-Dârimî, Abdülmu'min en-Nesefî ve Salih b. Cezre gibi şahsiyetler olduğu kaydedilerek bu kişilerin söylediklerinin eleştirisi yapılmıștır. Sonunda da Zehebî’nin Hasan b. Ziyâd hakkında ki olumlu ifadeleri paylaşılmıştır. Yazar; Yahyâ b. Maîn'in Hasan b. Ziyâd'ı yalanmasına, Hasan'ın hadis rivayet ederken vehmettiğini ve bunun cerh sebebi olmadığı yönündeki düşüncesiyle cevap vermiştir. İkincisi ise Şücâ‘ es-Selcî'dir. Kendisi hakkında İbn-i Adî’nin el-Kâmil adlı eserinde olumlu bir ifadenin olmadığı açıklanmıştır. Yazar; İbnü'l-Esîr'in Ebû Hanîfe ve mezhebi hakkında ki övgü dolu sözlerini paylaşarak, Şüca' es-Selcîye karşı zikredilen eleştirilere cevap vermiştir. Şuca' es-Selcî'nin Mücessime ve Müşebbihe’ye bağlı olduğu, hadisler uydurup kitaplarma iliştirerek Ehl-i Hadis'e nispet ettiği iddia edilmiştir. Yazar; Şuca'nın teşbih içeren hadisleri uyduran biri olduğundan cerh edildiğini belirttikten sonra buna dair gözle görülür bir kanıtın olmadığını ifade etmiştir. Yazar, son olarak Zehebî'nin Tarih'in de Şuca' es-Selcî hakkında gelen birkaç rivayete yer verip yorumlayarak noktayı koymuştur(83-136). İkinci bölümde ele alınan başlıklar yetersiz kalmaktadır. Mihne sürecine maruz kalmış sadece iki alim yoktur. Birçok alim bu süreci yaşamıştır. 0 alimlerden meşhur olanları konu edilebilinirdi. Diğer bir husus, bu bölümün üçüncü başlığında, Mihne dönemine ait bilgiler zikredilerek tekrara düşülmüştür. Bu durum okuyucu tarafından hoş görülmeyecektir. Çıkarılması veya yeniden ele alınması daha güzel olacaktır. Ayrıca Yazar, eleştiri yaparken daha yumuşak bir üslup kullanabilirdi. Mesela; sayfa 124'te geçen İbn Adî eleştirisinde böyle bir durum gözlemlenmiştir. 
Yazar, sonuç bölümünde; 1) Mihne ve Haşevilik'in birbiriyle ilişkili olduğu, 2) Hadis tarihini "Kitâbiyat" tarihine indirgemenin, hadis tarihi çizgisi dışına çıkaracağı, 3) Mihne olayının hadisçileri üretken bir (kitap yazmak vs.) noktaya getirdiği ve Haşeviyye olgusunun ortaya çıkmasında başat rol oynadığı, 4) Haşeviyye olgusunun mimarı, Ahmed b. Hanbel olarak benimsendiği ve kitleleri arkasına topladığı, 5) Haşeviyye tabirinin, bu düşüncenin sosyal tabanıyla beraber entelektüel tarafına da mesaj verdiği, 6) Haşevilik, Haricilik gibi sosyal ve duygusal yönüyle günlük hayatta etkin rol aldığı ve diğer fırkaların düşünsel düzlemde kaldığı, 7) Haşeviliğin Hanbelilikle ilişkilendirilmesinin yanlış olduğu belirtilerek hadis tarihinin bütünüyle incelenerek bu bağlantının varlığının olup olmadığına karar verilebileceği, 8) Mihne olayı ve Haşeviyye olgusunun, hadis literatürüne çok şey kattığı hususlarına yer vermiştir.

\section{Kaynakça}

Fayda, Mustafa. "Tarih". Türkiye Diyanet Vakfi Ansiklopedisi. Erişim 5 Kasım 2021. https://islamansiklopedisi.org.tr/tarih\#1

Özafşar, Mehmet Emin. İdeolojik Hadisçiliğin Tarihi Arka Planı. Ankara: Otto, 3. Basım, 2017. 